\title{
Recording Non-Labor Politics Through Biography
}

\section{Judith Brett}

In this contribution I shall address three issues: first, what questions do biographers ask of their subjects; second, why the history of non-Labor has been written largely through the prism of political biography; and, third, why have non-Labor people not been as assiduous in writing memoirs and autobiographies.

To date, I have written two essentially long political essays on Sir Robert Menzies and an essay on Sir Paul Hasluck. I am currently thinking about whether to do a biography of John Howard.

I essentially came to political biography from political science, rather than the other way around. And, I would argue, one's intellectual origins are important in this project. It does make a difference from where you come. Biographers from different backgrounds will pose different questions.

The questions I asked when working on Menzies focused on the basis of his popular appeal. This was the start but I moved from there to a biographical essay. It made me self-conscious of the sort of questions that I would ask in a biography and the way in which I would begin to analyse them. It seems to me that a 'political life' is not just a life that happens to be in politics. Rather, it is a life which is, in some sense, made by politics, and then captured by the political biographer. So, one of the main questions I would seek to ask is: what is the deep source of political energy for that person. What drives the subject especially as politics is essentially an uncertain business? Writing about Menzies - and if I were to do a biography of Howard - there are key questions concerning their political life I would want to try to understand first. What drove them? What were the circumstances and influences? Why did politics have a big attraction for them? How did politics satisfy their psychological needs and what pleasure did it give them?

A biographer reflecting on these questions gets a better sense of how their subject handled power and the political process: why the person wants it; what they want to do with it; how they use it when they have it and, equally, how they do not use it when they have it; what they hold back from; and how they give it up. The biographical project is speculative because it seems to me that we typically only observe how the person exercises power when you see them with it, or they give it up, or have it snatched from them. 
Secondly, the history of non-Labor has been mainly told through political biographies. I want to put forward some reasons why this might have been the case. Some of these are to do with the emphasis on leadership in the non-Labor political tradition. Given that the non-Labor parties are heirs to the nineteenth century leadership-based parliamentary parties, there is a certain rationale in telling the non-Labor story by telling the story of the leader - if not through their eyes, then at least centred on them. It makes sense in terms of their history. The political cohesion and policy direction of these parties were very much in the hands of the leadership, so it makes sense that that is the story to tell.

But there is more to it. The conservative side of politics tends to subscribe to the 'great man view of history', with an interest in the way an individual can make a difference and represent their time. Typical of the sort of biographies I am thinking of here is La Nauze (1965) on Alfred Deakin. It is not actually a very good biography at all, but it is a very good piece of political history. If you want to know what was going on in the formation of the nation and in Victorian politics at that time, then that is where you go to read about it. But you do not come away from La Nauze's study with a sense of a shaped political life. It seems to me that Deakin is somebody who is crying out for a new biographer along the lines of David Day's excellent biographies of Curtin (1999) and Chifley (2003).

There are arguably three partial biographies of Deakin. There is La Nauze; there is The Mystic Life of Alfred Deakin by Al Gabay (1992) that explores his spiritual life; and there is John Rickard (1996) who has done Deakin's women and his family life. But no-one, including La Nauze, has actually put these accounts together into an imaginatively conceived political life.

One of the reasons why there has been an emphasis on biography to tell the story of non-Labor is because of the weakness and fragmentation of their institutional and organisational records. We know a little of the story of the party's formation and reformation, and this is a really big contrast with Labor's political history where there has been a continuous, nationally organised party since Federation and where we have party people who take some care with the records.

On the non-Labor side of politics there are various electoral leagues but, until the formation of the Liberal party in the middle of the 1940s, these various electoral leagues came and went. They have different organisations with different party names in different states; they have different organisational structures in different states, with various short-lived splinter parties. There is an extremely weak co-ordinating centre. There is nothing much for the United Australia Party that even counts as the records of a party organisation. The strength of that party was in the state-based organisations that sustained it. Much of its political energy was actually exerted in the states. Today it would be difficult to publish a biography of state-based political activists and certainly not of the pre-war 
period. So maybe we can obtain a window through coalition biographies, where state-based activity and the holding of state powers was considered very important. Maybe, too, if we can think of producing some forms of collective biographies, this might be one way we could conceivably write about that period of history and publish that sort of material now.

The weakness and fragmentation of the various organisations is mirrored in the poor evidence base. Apart from biographies, there is an incredibly thin, fragmented and scattered archival base for writing the organisational history of the non-Labor side. There are personal papers but no organisational papers as there is for Labor. This relates to the different formations of the major parties - when the Liberal Party was formed in the 1940s nobody kept the records of the United Australia Party. Most records would have been kept in the state branches and what survived is a very hit and miss affair, and most of what has survived is in personal papers. One reason why the non-Labor story has been told through the lives of leaders is because of the relatively greater access to their personal papers.

This also accounts for the fact that so many of the political biographies of conservatives - such as that of Deakin - and I think this is also true of the biography of Menzies (Martin 1993; 1999) — are weighed down with levels of political detail. There is nowhere else for political detail to be told if it is not told in these biographies. To some extent the large size of some of these political lives is because of the thinness of Australian political history. They are not just about lives but about ways of telling organisational history or the history of intellectual traditions. This can be seen in Inga Clendinnen's essay (2004) on Allan Martin's biographical output. As she describes it, he started out by suggesting interesting biographical questions, thematic questions, thinking that he will shape a life around these questions in a less conventional and more probing way. But he ended up in his studies both of Parkes (1980) and Menzies (1993; 1999) writing very standard, chronological, huge biographies weighed down with political detail.

These biographers are not just writing a biography but piecing together the political record. Without biographies these long periods of political experience would never be written. But it makes these biographies tome-like works because they are more of a vehicle for the telling of political history. The political biography of a conservative is arguably compromised by the need to write the non-Labor history of Australia.

Finally, there is the question of why is it that the Liberals or non-Labor politicians do not write about their own political lives? Why are there fewer autobiographies or memoirs of non-Labor political figures? Do they not view their experiences as remarkable or interesting? Are Coalition leaders less inspiring to the 
biographical imagination? One would not presume so, but we have been hardly trampled in the rush to publish non-Labor autobiographies.

Occasionally some conservative politicians have gone into print. Deakin (1944) and Hasluck $(1977 ; 1980 ; 1997)$, both of whom can be counted as being on the non-Labor side, are our intellectuals in politics and have written reflectively or produced material to some extent. There are also memoirs by people like Percy Spender (1969; 1972) and Howard Beale (1977). But not much has come out in more recent years.

I have thought about these issues for quite some time. And I wonder whether it is related to their philosophical experiences and attitudes to time/history. Liberals believe their party is a party of material progress; it is the heir to the optimism of the nineteenth century political experience in the colonies. Their beliefs reflect the building of a new land, the hardships and hard culture that people endured. Conservatives consider they have built prosperity and added societal materialism to the nation building project. They look more to the future while the past is just not of interest. The lack of memoirs or autobiographies of conservative politicians may be a function of the emptiness of a historical imagination - an inevitable consequence it seems to me of that colonial nation building project.

In my own research I noticed time and again when I was reading through the personal papers of various politicians, how often the phrase, 'the past is behind us, we must look to the future,' comes up in Liberal Party documents. Deakin used the phrase. Malcolm Fraser used it in his day. Alexander Downer used almost exactly the same phrase at the beginning of his ill-fated leadership in 1994. There is no sense of nurturing the past. The past is to be left to rest, not celebrated. This may be due to the party's fractured and turbulent experiences. The party's history during the previous century is but a series of new beginnings and rebirths. It makes sense that they do not want to dwell on their failures and, apart from Menzies, there are no heroes for them. 